\title{
STUDY OF S. N-TELOPEPTIDE, A BONE RESORPTIVE BIOMARKER IN POST-MENOPAUSAL OSTEOPOROSIS
}

\author{
Sunithapriya P1, Sasivathanam Natarajan², Thirumalaipandiyan Dhanapandiyan ${ }^{3}$ \\ ${ }^{1}$ Assistant Professor, Department of Biochemistry, Thanjavur Medical College, Thanjavur, Tamilnadu. \\ 2Professor, Department of Biochemistry, Thanjavur Medical College, Thanjavur, Tamilnadu. \\ ${ }_{3}^{3}$ Assistant Professor, Department of Orthopaedics, Thanjavur Medical College, Thanjavur, Tamilnadu.
}

\begin{abstract}
\section{BACKGROUND}

Osteoporosis is a metabolic bone disorder characterised by low bone mass associated with microarchitectural deterioration of bone tissue leading to enhanced bone fragility and an increase in fracture risk. Postmenopausal osteoporosis is characterised by a hormone-dependent acceleration of bone loss that occurs after menopause. Serum N-Telopeptide, a bone resorptive biomarker helps to identify the post-menopausal woman with high bone turnover rate and thereby helps in predicting their future fracture risk.
\end{abstract}

\section{AIMS AND OBJECTIVES \\ The present study aims to measure S. N-Telopeptide level in postmenopausal women and to compare it with healthy premenopausal women and to evaluate the relationship between N-Telopeptide, BMD and oestrogen.}

\section{MATERIALS AND METHODS}

Study group included 50 postmenopausal women aged 50-70 years who were not previously diagnosed as osteoporosis and who had BMD T-score $\geq-2.5$ and T-score between -1.0 to -2.5 . Control group include 50 premenopausal women aged 25-35 years. S. NTelopeptide and Oestrogen were measured by ELISA method. BMD was assessed by ultrasonography taken in heel and the T-scores were recorded.

\section{RESULTS}

Results were expressed as mean \pm SD and were statistically analysed using SPSS software version 16 , student's t-test and Pearson's correlation coefficient. The mean range of S. N-Telopeptide in the study group (101.47 nmol BCE/L) is significantly higher than the control group mean (17.35 nmol BCE/L) and the p value is statistically significant. Pearson's correlation studies showed a negative correlation between $\mathrm{N}$-telopeptide and BMD, Oestrogen, BMI which is statistically significant.

\section{CONCLUSION}

The present study shows that there is a significant increase in serum N. Telopeptide level in postmenopausal women and it correlates well with the degree of osteoporosis.

\section{KEYWORDS}

N-Telopeptide, Post-Menopausal Osteoporosis, Oestrogen, BMD, BMI.

HOW TO CITE THIS ARTICLE: Sunithapriya P, Natarajan S, Dhanapandiyan T. Study of S. N-Telopeptide, a bone resorptive biomarker in post-menopausal osteoporosis. J. Evolution Med. Dent. Sci. 2016;5(76):5657-5660, DOI: 10.14260/jemds/2016/1276

\section{INTRODUCTION}

Osteoporosis is a metabolic bone disorder characterised by decreased bone mass and an increased susceptibility to fractures secondary to trivial trauma.(1) In the new millennium as we reap the stupendous advances in medical sciences, we are faced with new problems of "ageing." Osteoporosis is a silent epidemic. Nearly $14 \%$ of postmenopausal women and $8 \%$ of men above 50 years of age have osteoporosis.(2) The hallmark of osteoporosis is, in its predisposition to fracture following relatively a minor trauma. At the age of 50, women have a lifetime fracture risk of about $40 \%$. World Health Organisation operationally defines osteoporosis as a bone

Financial or Other, Competing Interest: None.

Submission 15-08-2016, Peer Review 10-09-2016,

Acceptance 16-09-2016, Published 22-09-2016.

Corresponding Author:

Dr. Sunithapriya $P$,

121, Sundaram Nagar, $6^{\text {th }}$ St

Medical College Road,

Thanjavur-613004.

E-mail: sunithapandiyan@gmail.com

DOI: $10.14260 /$ jemds $/ 2016 / 1276$

\section{(c) $(1) \ominus$}

density that falls 2.5 Standard Deviations (SD) below the mean for young healthy adults of the same gender - also referred to as a T-score of -2.5. WHO technical report series - 843 predicts a significant increase in fracture neck of femur among Asian population over a period of time.(3) By 2050, osteoporosis will be a major demographic factor due to changes in lifestyle and the increase in survival rate of elderly.

Ageing is the major risk factor, because after 35-40 years of age, bone resorption slightly exceeds bone formation so that approximately $1 \%$ of skeletal bone is lost per year. In women the decrease in sex steroids at menopause accelerates the bone loss to about $2 \%$ per year for the first five years and then declines to $1 \%$ loss per year.(4),(5),(6)

Post-menopausal osteoporosis is characterised by a hormone-dependent acceleration of bone loss that occurs after menopause. In regard to post-menopausal osteoporosis, decreased quantity of sex hormone mainly "oestrogen" is the prime factor that results in unbalanced bone remodelling. Decreased oestrogen level results in increased production of cytokines like IL-1, IL- 6 and TNF by blood monocyte and bone marrow cells. These cytokines in turn mediates osteoclast recruitment and activity, by increasing the levels of RANK and 
RANK-L and decreasing the activity of osteoprotegerin.(7) Compensatory osteoblastic activity occurs, but it does not keep in pace, leading to osteoporosis.(8),(9)

Till menopause there will be gradual thinning of trabeculae and then there is an abrupt acceleration in the rate of bone loss. This accelerated bone loss persists for about 5-10 years and is accompanied by a dramatic increase in the bone turnover rate. The rapid bone loss experienced after menopause is not the result of osteoblastic insufficiency, but rather is due to increased osteoclastic activity. Incidence of fracture risk varies between men and women and it is due to their difference in their areal BMD, bone size geometry and bone strength.(10),(11)

Early the diagnosis will reduce the morbidity and mortality rate, but the diagnosis of osteoporosis is complicated by the fact that routine X-rays are not sensitive enough to pick up osteoporosis at an early age.(12) It has been estimated that nearly $40 \%$ of skeletal bone mass is lost before the X-ray shows the sign of osteopenia. Further osteoporosis does not reveal any consistent metabolic abnormality detected by standard laboratory tests and certainly it is very difficult to predict a fracture at a given time in specific person. ${ }^{(13)}$

Diagnosis of osteoporosis is made clinically by quantifying the bone mineral density. Recently, new bone turnover markers have been used in attempt to get a better insight into bone microarchitecture and they appear as a promising tool for defining the skeletal status of post-menopausal women.

Bone turn over markers are useful inexpensive tools for studying bone metabolism in population studies and they also predict fracture risk independent of bone mineral density High bone turnover per se can disrupt trabecular architecture by increasing the incidence of trabecular perforation and buckling, thus reducing bone strength without necessarily affecting bone mineral density substantially.(14)

$\mathrm{N}$-telopeptide is a stable degradation end product from type- 1 collagen. In bone type- 1 collagen is formed by two $\alpha$ (1) and one $\alpha$ (2) chains stabilised by the formation of pyridinium cross links, pyridinoline and deoxypyridinoline in the telopeptide region. During bone resorption, type- 1 collagen is degraded, yielding smaller fragments like N-Telopeptide, CTelopeptide, pyridinoline and deoxypyridinoline in circulation making these fragments available as markers of bone resorption.(15)

In view of the above facts, the present study was done on serum $\mathrm{N}$-Telopeptide, a bone resorptive biomarker to identify the post-menopausal woman with high bone turnover rate and also helps to identify their future fracture risk. The $\mathrm{N}$ Telopeptide assay measures N-Telopeptide linked pyridinoline and deoxypyridinoline in serum and the results are expressed as bone collagen equivalents.

\section{MATERIALS AND METHODS}

This study was carried out in the Department of Biochemistry, Thanjavur Medical College Hospital, Thanjavur, India, after getting approval from the Ethical Committee. Written informed consent was obtained from the participants. This case control study is prospective and it was conducted for a period of 6 months.

\section{Study Group}

Study group included postmenopausal women aged 50-70 years who were not previously diagnosed as osteoporosis and who had BMD T-score $\geq-2.5$ and T-score between -1.0 to -2.5 . Women with h/o Diabetes mellitus, kidney diseases, thyroid dysfunction and with $\mathrm{h} / \mathrm{o}$ of steroid intake were excluded from the study. The study participants did not take any medications known to affect the endocrine status for at least three months prior to the study.

\section{Control Group}

Control group include premenopausal women aged 25-35 years without any specific illness. Standard anthropometric measurements which include height, weight, BMI were calculated from both study and control group.

\section{Sample Collection}

Under aseptic conditions, $5 \mathrm{~mL}$ of venous blood was collected from each subject. The vacutainers containing the blood samples were kept at room temperature for 30 minutes and then centrifuged at $2000 \mathrm{~g}$ for 15 minutes for clear separation of serum. The aliquot of serum was stored at $-20^{\circ} \mathrm{C}$ in the deep freezer for estimation of serum $\mathrm{N}$-Telopeptide and serum oestrogen.

Serum N-Telopeptide and serum oestrogen were measured by ELISA method.

BMD was assessed by ultrasonography taken in heel and the T-Scores were recorded.(16),(17)

\section{STATISTICAL ANALYSIS}

Results were expressed as mean $\pm \mathrm{SD}$ and were statistically analysed using SPSS software version 16 and MS Excel. Student's t-test was used to analyse the difference between the two groups. Relationship between the variables were evaluated using Pearson's correlation coefficient. A p-value < 0.05 was considered to be statistically significant.

\section{RESULTS}

[Table/Fig.-1] shows the association between age of the respondents and their study and control group. [Table/Fig.-2] shows the comparison of parameters between cases and healthy controls which was as follows: Serum N-Telopeptide in study group is $101.47 \pm 18.39 \mathrm{nmol} \mathrm{BCE} / \mathrm{L}$, which is higher than the control group mean $17.35 \pm 3.2 \mathrm{nmol} \mathrm{BCE} / \mathrm{L}$ which is statistically significant ( $p<0.05)$. Further, mean serum Oestrogen level in study group $(13.14 \pm 2.3 \mathrm{pg} / \mathrm{mL})$ is lower than control group mean serum oestrogen level $(125.78 \pm 34.79$ $\mathrm{pg} / \mathrm{mL})$, which is statistically significant $(\mathrm{p}<0.05)$.

Table/Fig.-3 Association of BMD in control and study group.

Table/Fig.-4 shows the Pearson's correlation between NTelopeptide and other study parameters. We found a negative correlation between N-Telopeptide and Oestrogen, BMD and BMI which is statistically significant.

\begin{tabular}{|c|c|c|c|c|}
\hline \multirow{2}{*}{$\begin{array}{c}\text { Sl. } \\
\text { No } \\
\text {. }\end{array}$} & \multirow[b]{2}{*}{ Age } & \multicolumn{2}{|c|}{ Group } & \multirow{2}{*}{$\begin{array}{l}\text { Statistical } \\
\text { Inference }\end{array}$} \\
\hline & & $\begin{array}{c}\text { Study } \\
(n=50)\end{array}$ & $\begin{array}{l}\text { Control } \\
(n=50)\end{array}$ & \\
\hline 1 & $\begin{array}{c}\text { Below } 30 \\
\text { yrs. }\end{array}$ & 0 & $18(36 \%)$ & \multirow{5}{*}{$\begin{array}{c}\mathrm{X}^{2}=100.000 \\
\mathrm{Df}=6 \\
.000<0.05 \\
\text { Significant }\end{array}$} \\
\hline 2 & $\begin{array}{c}31 \text { to } 35 \\
\text { yrs. }\end{array}$ & 0 & $31(62 \%)$ & \\
\hline 3 & $\begin{array}{c}36 \text { to } 40 \\
\text { yrs. }\end{array}$ & 0 & $1(2 \%)$ & \\
\hline 4 & $\begin{array}{c}51 \text { to } 55 \\
\text { yrs. }\end{array}$ & $\begin{array}{c}14 \\
(28 \%) \\
\end{array}$ & 0 & \\
\hline 5 & $\begin{array}{c}56 \text { to } 60 \\
\text { yrs. }\end{array}$ & $\begin{array}{c}25 \\
(50 \%)\end{array}$ & 0 & \\
\hline
\end{tabular}




\begin{tabular}{|c|c|c|c|c|}
\hline 6 & $\begin{array}{c}61 \text { to } 65 \\
\text { yrs. }\end{array}$ & $7(14 \%)$ & 0 & \\
\hline 7 & $\begin{array}{c}66 \text { to } 70 \\
\text { yrs. }\end{array}$ & $4(8 \%)$ & 0 & \\
\hline \multicolumn{4}{|c|}{ Table 1: Association between Age of the Respondents } \\
and their Study and Control Group
\end{tabular}

\begin{tabular}{|c|c|c|c|c|}
\hline $\begin{array}{l}\text { Sl. } \\
\text { No. }\end{array}$ & Parameter & $\begin{array}{c}\text { Control } \\
(n=50)\end{array}$ & $\begin{array}{c}\text { Study } \\
(n=50)\end{array}$ & $\begin{array}{l}\text { Statistical } \\
\text { Inference }\end{array}$ \\
\hline 1 & $\begin{array}{c}\text { S. N- } \\
\text { Telopeptide }\end{array}$ & $\begin{array}{l}17.35 \pm \\
3.23\end{array}$ & $\begin{array}{r}101.47 \\
\pm 18.39\end{array}$ & $\begin{array}{l}.0001<0.05 \\
\text { significant }\end{array}$ \\
\hline 2 & S. Oestrogen & $\begin{array}{l}125.78 \pm \\
34.79\end{array}$ & $\begin{array}{c}13.14 \pm \\
2.31\end{array}$ & $\begin{array}{l}.0001<0.05 \\
\text { significant }\end{array}$ \\
\hline 3 & BMD & $\begin{array}{c}-0.82 \pm \\
0.19\end{array}$ & $\begin{array}{l}-2.76 \pm \\
0.27\end{array}$ & $\begin{array}{c}.0001<0.05 \\
\text { significant }\end{array}$ \\
\hline 4 & BMI & $\begin{array}{l}22.83 \pm \\
2.55\end{array}$ & $\begin{array}{l}24.092 \\
\pm 3.47\end{array}$ & $\begin{array}{c}0.043<0.05 \\
\text { significant }\end{array}$ \\
\hline \multicolumn{5}{|c|}{$\begin{array}{l}\text { Table 2: Comparison of Parameters } \\
\text { between Study and Control Group }\end{array}$} \\
\hline
\end{tabular}

\begin{tabular}{|c|c|c|c|c|}
\hline \multirow[b]{2}{*}{$\begin{array}{c}\text { Sl. } \\
\text { No. }\end{array}$} & \multirow[b]{2}{*}{ BMD } & \multicolumn{2}{|c|}{ Group } & \multirow{2}{*}{$\begin{array}{l}\text { Statistical } \\
\text { Inference }\end{array}$} \\
\hline & & $\begin{array}{c}\text { Study } \\
(n=50)\end{array}$ & $\begin{array}{l}\text { Control } \\
(n=50)\end{array}$ & \\
\hline 1 & Less than-1 & 0 & $\begin{array}{c}50 \\
(100 \%) \\
\end{array}$ & \multirow{3}{*}{$\begin{array}{c}\mathrm{X}^{2}=100.000 \\
\mathrm{Df}=2 \\
.0001<0.05 \\
\text { Significant }\end{array}$} \\
\hline 2 & -1 to -2.5 & $\begin{array}{c}8 \\
(16 \%) \\
\end{array}$ & 0 & \\
\hline 3 & $>-2.5$ & $\begin{array}{c}42 \\
(84 \%)\end{array}$ & 0 & \\
\hline \multicolumn{5}{|c|}{$\begin{array}{l}\text { Table 3: Association of BMD in } \\
\text { Control and Study Group }\end{array}$} \\
\hline
\end{tabular}

\begin{tabular}{|c|c|c|}
\hline $\begin{array}{c}\text { Study } \\
\text { N-Telopeptide }\end{array}$ & $\begin{array}{c}\text { Correlation } \\
\text { Value }\end{array}$ & $\begin{array}{c}\text { Statistical } \\
\text { Inference }\end{array}$ \\
\hline BMI & $-.372\left(^{* *}\right)$ & $\begin{array}{c}\mathrm{P}<0.01 \\
\text { significant }\end{array}$ \\
\hline Oestrogen & $-.745\left(^{* *}\right)$ & $\begin{array}{c}\mathrm{P}<0.01 \\
\text { significant }\end{array}$ \\
\hline BMD & $-.746\left(^{* *}\right)$ & $\begin{array}{c}\mathrm{P}<0.01 \\
\text { significant }\end{array}$ \\
\hline \multicolumn{2}{|c|}{ Table 4: Pearson's Correlation between $\mathbf{N}$-Telopeptide } \\
and other Study Parameters
\end{tabular}

\section{DISCUSSION}

In the era of increased lifespan and longevity, osteoporosis is the major public health problem. Osteoporosis is the "silent killer," the individual is usually asymptomatic while the disease follows a relentless course. Only the tip of the iceberg is noticed and the remaining goes for devastating complications like fractures.

The Gold standard in the diagnosis of osteoporosis is the evaluation of BMD by DEXA scan, which is not only expensive but also rare in availability. The traditional markers of bone resorption like urinary hydroxyproline and calcium are not highly specific and sensitive. There is always a need felt to have a reliable, non-invasive, cost effective, easy accessible and readily available investigation marker to diagnose osteoporosis.

In the present study with 100 subjects, we measured serum N-Telopeptide, a bone resorptive biomarker to assess the quality of bone in post-menopausal women and compared it with healthy premenopausal women. The strength of the study lies in the fact that both serum N-Telopeptide and BMD measurements were simultaneously assessed in elderly population and in normal young female.

Comparison of mean value of serum N-Telopeptide of the study group $(101.47 \pm 18.39)$ with that of control group $(17.35 \pm 3.23)$ showed a significant rise in the study group. This shows that there is increased rate of bone resorption following menopause. This study also correlates with the previous studies done by N. Jayaram et al.(18)

Further, in our study we observed that the mean oestrogen level in the study group (13.14 \pm 2.3$)$ is significantly low when compared to the control group $(125.78 \pm 34.79)$ and the $p$ value is statistically significant. This result clearly supports the pathogenesis that post-menopausal osteoporosis is the hormone dependent acceleration of bone loss, which occurs after menopause.

The mean BMD in the study group $(-2.766 \pm 0.27)$ is significantly low when compared to that of control group $(-0.82 \pm 0.195)$.

The mean age of the study group is 58.8 years and the mean age of the control group is 31.5 years. Pearson's correlation studies showed a positive relationship between age and serum $\mathrm{N}$-Telopeptide and a negative relationship between age and other parameters like BMD and Oestrogen. These findings supports the fact that the ageing microenvironment also contributes to decreased formation of bone due to decreased proliferating capacity of osteogenic cells. Since the mean age of the study is 58.8, this correlates with the current scenario that osteoporosis occurs in Indian population 1 to 2 decades earlier than Western population.(19)

Within our study group of 50 individuals, 5 individuals have BMI $<20$ and their serum N-Telopeptide levels were significantly high when compared to other individuals within the study group. This shows that thin built individuals are at high risk of developing osteoporosis than obese individuals.

Thin built women are at higher risk than obese women, particularly of their low oestrogen production, their lower concentration of circulating oestrogen, and the decreased mechanical stress on their bone.(20)

Obese individuals have larger body mass, which imposes greater mechanical load on bone, thereby increasing the bone mass. Further adipocytes are important source of oestrogen in post-menopausal women, which inhibits bone resorption by osteoclasts. These observations finally suggests that the level of S. N-Telopeptide, the cross-linked collagen peptides increases with bone resorption and can be used as a reliable marker in primary post-menopausal osteoporosis.

\section{LIMITATION}

Our study is limited by very small sample size. Neither PTH nor Vitamin D, the regulators of mineral metabolism are included in the study.

Further, variations that occur due to seasonal changes increased bone resorption during winter than summer are not considered in the study.

\section{CONCLUSION}

Present study demonstrated a significant increase in serum NTelopeptide level in post-menopausal women and it correlates well with the degree of osteoporosis. Further, measurement of serum $\mathrm{N}$-Telopeptide also helps to identify the individuals having high bone resorption rate and hence increased fracture risk. Hence, earlier interventional measures both by dietary 
and pharmacological means can be taken to reduce fracture and its complications.

\section{Scope for the Future Study}

Osteoporosis is a complex, multifactorial, polygenic disease in which genetic determinants are modulated by hormonal, nutritional and environmental factors. In post-menopausal osteoporosis, deficiency of oestrogen plays a major role in bone loss. Oestrogen regulates bone homeostasis by acting through ER $\alpha$ and ER $\beta$. These receptors are the members of the nuclear receptor super family, which act as ligand activated transcription factors. Different polymorphisms have been reported in ER $\alpha$ and ER $\beta$ genes. Studies can be done in future to determine the contributions of these polymorphism in the pathogenesis of osteoporosis and also to define the functional molecular consequences in the causation of osteoporotic phenotype.

Pharmacotherapy for osteoporosis has been mainly focused on interventions that could reverse excessive bone resorption. CDNA analysis studies have shown that Cathepsin $\mathrm{K}$, a protease which degrade protein matrix of the bone is expressed at high levels in the contact site between osteoclast and bone resorption pit. This provides a scope for the development of new antiresorptive drugs like Cathepsin $\mathrm{K}$ inhibitors in the treatment of osteoporosis.

\section{REFERENCES}

1. Cosman F, Dempster D. Pathogenesis of osteoporosis. Metabolic bone diseases. In: Hochberg MC, Silman AJ, Smolen JS, et al. eds. Rheumatology. $4^{\text {th }}$ edn. Philadelphia: Mosby Elsevier Publication 2008:193.

2. Goregoankar $\mathrm{AB}$, Phalak $\mathrm{M}$, Joshi D. Markers of osteoporosis. Current status and role in osteoporosis. Orthopaedics Today 2011;13(1).

3. Chaudhary LJ, Kumar R. Osteoporosis: investigations helping early diagnosis. Orthopaedics Today 2010;12(1).

4. Wali JP, Handa R, Aggarwal P. Osteoporosis. In: Sharma OP, ed. Geriatric care in India. $3^{\text {rd }}$ edn. New Delhi: Viva Books Pvt Ltd 2008:305-6.

5. Risteli J, Winter WE, Kleerakoper $M$, et al. Bone and mineral metabolism. In: Burtis CA, Ashwood R, Burns E, eds. Tietz textbook of clinical chemistry and molecular diagnostics. $5^{\text {th }}$ edn. Philadelphia: Elsevier Saunders 2012:1778-80.

6. Seeman E. Modeling and remodelling. In: Bilezikein JP, Raisz LG, Martin J, eds. Principles of bone biology. $3^{\text {rd }}$ edn. Vol.1. San Diego: Academic Press 2008:18.
7. Teitelbaum SL. Postmenopausal osteoporosis, T Cells and immune dysfunction. PNAS USA 2004;101(48):16711-2.

8. Rosenberg AE. Bones, joints and soft tissue tumors. In: Kumar V, Robbins SL, Cotran RS, eds. Robbins and Cotran pathologic basis of disease. 8 $^{\text {th }}$ edn. Philadelphia: Saunders Elsevier 2010:1214-5.

9. McCarthy EF, Frassica FJ. Metabolic bone diseases. Pathology of bone and joint disorders with clinical and radiological correlation. $1^{\text {st }}$ edn. Philadelphia: WB Saunders Company 1991:91.

10. Cawthon PM. Gender differences in osteoporosis and fractures. Clinical Orthopaedics and Related Research 2011;469(7):1900-5.

11. Huilgol SV, Tadvi NA. Bisphosphanates-newer therapeutic strategies in prevention and treatment of osteoporosis. Orthopaedics Today 2011;13(1).

12. Bukata SV, Roiser RN. Metabolic bone diseases and osteonecrosis. In: Greene WB, ed. Netter's orthopaedics. $1^{\text {st }}$ edn. Philadelphia: WB Saunders 2006:33-4.

13. Vigorita VJ. Metabolic bone diseases. Orthopaedic pathology. 2nd edn. Philadelphia: Wolters Kluwer/ Lippincott Williams \& Wilkins 2008:112.

14. Eastell R, Hannon RA. Biomarkers of bone health and osteoporosis risk. Procceedings of the Nutrition Society 2008;67(2):157-62.

15. Maeno Y, Inaba M, Okuno $S$, et al. Serum concentrations of cross linked N-telopeptides of type I collagen: new marker for bone resorption in hemodialysis patients. Clinical Chemistry 2005;51(12):2312-7.

16. Mukherjee $\mathrm{S}$. Investigations and diagnosis of bone disorders. In: Munjal YP, ed. API textbook of medicine. $9^{\text {th }}$ edn. Vol.1. New Delhi: Jaypee Publications 2012:302.

17. Lerner UH. Bone remodeling in postmenopausal osteoporosis. Journal of Dental Research 2006;85(7): 584-95.

18. Jayaram N, Bijoor AR, Rajagopalan N, et al. The value of serum and urinary $\mathrm{N}$-telopeptide in the diagnosis of osteoporosis. Indian Journal of Orthopaedics 2002;36(2):9.

19. Mukherjee S, Ghosh A. Osteoporosis-the new global epidemic. In: Single A, Deodhar SD, eds. Rheumatology principles and practice. $1^{\text {st }}$ edn. New Delhi: Jaypee Publication 2010:297-8.

20. Kelsy JL. Musculoskeletal disorders. In: Wallace RB, Kohatsu N, eds. Public health and preventive medicine. $15^{\text {th }}$ edn. USA: McGraw Hill Publication 2007. 